\title{
Phenomenon-Based Research in International Business: Making IB Relevant Again
}

\section{Jonathan Doh, Villanova University, USA}

\section{Introduction}

International business scholars have made a habit of reflecting on their contributions to academic research and the shortcomings associated with them. These reflections may be seen in the broader context of mounting questions and concerns about the relevance of business school education and the role of academic research in the business school enterprise. I trace this wave of reviews and reconsiderations to the essay by the late Sumantra Ghoshal (2005) where he argued that our core management theories have distracted us from the important challenges facing managers, and where he further asserted that these theories are often ethically problematic.

In another widely cited piece, Pfeffer and Fong (2002) debunked conventional wisdom about the value of an MBA degree, while Mintzberg and Gosling (2002) argued for real-world training in global settings to develop globally relevant managerial skills and aptitudes. In the introduction of a recent issue devoted to the "The Legitimacy and Impact of Business Schools," Andrew Pettigrew and Ken Starkey (2016) reviewed the modern literature that has frequently questioned the role and impact of business schools on a range of grounds such as the emphasis on professionalism and careerism over a broader liberal education, and the advocacy of a capitalistic, neoliberal approach to all social and economic challenges (see also Henisz, 2011; Khurana, 2007).

In the world of international business (IB), arguments have tended to center around its legitimacy as a field separate and apart from management, economics, and other disciplines, and the issue of what questions IB scholars should focus on. In this article, I make the case that a return to more phenomenon-based research is a potentially fruitful response to many of these criticisms, and one that could help re-establish the field as a leading contributor to scholarly research but also of a practical impact on both public policy and corporate strategy.

\section{What Is Phenomenon-Based Research?}

A number of scholars have attempted to define and delineate phenomenon-based research from other forms of scholarship. For example, Von Krogh, Rossi-Lamastra and Haefliger (2012: 278) argued that this type of research is designed to "capture, describe and document, as well as conceptualize, a phenomenon so that appropriate theorizing and the development of research designs can proceed." Echoing some of the critiques of management scholarship mentioned above, they point to many calls from senior scholars for greater attention to phenomena. Specifically, they quoted Hambrick (2007: 1346, as cited in Von Krogh et al., 2012: 278) who argued that too strong a focus on theory is likely to "prevent the reporting of rich details about interesting phenomena for which no theory yet exists."

While Von Krogh and his co-authors (2012) stated that phenomenon-based research is inherently proto-theoretic, I have argued that phenomenon-based research is any research that "takes as a principal focus the ability to accurately and insightfully inform a real-world phenomenon or phenomena" (Doh, 2015: 609). Indeed, one could reasonably expect all research in business to have this basic quality although Hambrick (2007) and others have observed that business research, especially the one emanating from the management disciplines, has increasingly required: (1) the development of elaborate and often abstract theories to underlie it and (2) increasingly sophisticated methodologies to test those theories. While these qualities are not in and of themselves negative or exclusionary, it does seem that they exist at the expense of demonstrated connections to real-world phenomena.

\section{Defining International Business as a "Row" Discipline}

Former Journal of International Business Studies Editor-in-Chief Lorraine Eden frequently argued that IB is a "row" rather than 
a "column" discipline. That is, IB seeks to highlight and explore the international dimensions of our core social and behavioral science disciplines of economics, management, finance, marketing, and related areas - the "columns." More importantly, simply investigating the international dimensions of these disciplines is not enough because IB research has to show how more than one of these areas may be necessary to fully inform the study of a given phenomenon. In this regard, Shenkar (2004) argued that this synergistic quality is IB's "special sauce" - my words, not his.

To me, this ability to integrate insights from multiple perspectives and bring them to bear on a given phenomenon is the core contribution of IB research. As such, IB has the potential - and responsibility - to add up to more than the sum of its disciplinary parts. Indeed, IB research is uniquely positioned to contribute to understanding modern phenomena, and it is well-situated at the intersection of other disciplines and fields to do so.

\section{Answering Big Questions}

Another frequent point of IB reflection is the issue of what questions it should explore. In an exchange in JIBS some years ago, several scholars argued that IB research should tackle big questions, and they offered suggestions for what these questions should be. Buckley (2002) lamented that IB might be running out of steam, while Peng (2004) proposed a tantalizingly simplistic interpretation of IB's core question - namely, "What contributes to the success or failure of firms in international markets?"

Recently, as Editor-in-Chief of the Journal of World Business, I oversaw the compilation of a 50th anniversary issue of the journal that included multiple reviews of IB literature streams. I was struck by the degree to which IB scholarship, in its early days, was often focused on tackling real-world problems related to the impact of policies toward multinational enterprises, to trade and investment agreements between and among countries, to issues of environment and development, and to many other realistic issues. As such, I believe that returning to some of those issues and questions will help re-energize IB scholarship while also providing valuable insights that could ultimately have relevance for policy and practice.

\section{Adhering to a Narrow View of Capitalism}

A related issue in debates among IB scholars and in the broader scholarly management community revolves around an increasing tendency to blindly incorporate assumptions about capitalistic markets that do not necessarily conform with reality. In the economic field, behavioral approaches have upended many long-held beliefs about how markets and the individuals who populate them make decisions. It is surprising that the international business field has not been subjected to similar pressures to revisit some of its core assumptions. Still, Shenkar (2004) took the field to task for its tendency to focus almost exclusively on its economic origins and paradigms as opposed to those emanating from anthropology, political science, and sociology. In his view, IB is broader than what is sometimes simply seen as the international dimensions of strategy, and Shankar emphasized its cross-cultural and comparative dimensions. Such a view would help extract IB from its over-emphasis on economic tools and measures, and leverage its broader social sciences connections and potential contributions.

Besides, Henisz (2011) has argued that the financial crisis underscored the need for business school research to leverage the range of social science research methods and to acknowledge the heterogeneity of national institutions, practices, and approaches to social and economic structuration. In particular, he called on scholars to acknowledge and integrate the role and position of civil society actors within the study of global political and economic issues - something which Teegen, Doh and Vachani (2004) also promoted in their assertion that non-governmental actors (NGOs) are legitimate subjects of IB research. With its sometimes compulsive focus on financial performance as the end-all of outcome variables, the strategy and IB fields have overlooked critical phenomena in the global environment, that are fundamental not just to the performance of firms but also to the functioning of modern societies.

\section{Phenomenon-Based IB Research}

Delios (2017: 391) recently observed the following:

- The world of IB is vibrant and stimulating. IB research is not.

- Managers in IB are energetic, creative and risk-taking. Modern-day IB scholars are not.

- Media stories covering IB are novel, engaging, and eye-catching. Recent IB journal publications are not.

While Delios' views may overstate the case, they are valid and deserve serious attention. Earlier on, Collinson, Buckley, Dunning and Yip (2006) as well as Collinson, Doz, Kostova, Liesch and Roth (2013) voiced similar concerns, although they were not presented quite so starkly or directly. In this issue, Collinson focuses on three related issues that have prevented - or, at least, constrained - IB scholarship from realizing its full potential in an environment that would seem ripe for the insights IB scholars may provide: (1) the incentive structures we are embedded in, (2) the declining relevance of what we know, and (3) the legitimacy of what we are doing regarding important stakeholders. I take issue with his second point because I believe that IB scholars are in fact highly knowledgeable about current global phenomena and have the potential to make important contributions to current debates. However, due to Collinson's first condition, we 
rarely have opportunities to convey it to our colleagues and the broader public. We are left to use op-eds, blogs, and other brief commentaries, and with precious few "scholarly" outlets interested in publishing more applied, direct, and relevant insights.

As Collinson points out, the range of contemporary phenomena requiring the kind of training and perspective which IB scholars possess is extensive - from Brexit to the political origins of economic crises in Brazil, to China's transition from a saving to a consumption economy, and to the rise of anti-globalization in the United States and Europe - and the IB field has all the tools necessary and talents to shed light on and inform these topics. However, a real upheaval may be required in order to encourage and incentivize scholars to pursue this kind of applied research. There are good examples of it but they are few and far between. We owe it to ourselves and our communities to make the efforts, take the risks and pursue the important questions. By committing ourselves to phenomenon-based research, we can begin this important transition.

\section{References}

Collinson, S. C., Buckley, P., Dunning, J., \& Yip, G. 2006. New directions in international business. In F. M. Fai \& E. J. Morgan (Eds), Managerial issues in international business. London: Palgrave.

Collinson, S. C., Doz, Y., Kostova, T., Liesch, P., \& Roth, K. 2013. Defining a domain for international business study. AIB Insights, 13(1): 3-9.

Doh, J. P. 2016 . From the Editor: Why we need phenomenon-based research in international business. Journal of World Business, 50(4): 609-611.

Mintzberg, H., \& Gosling, J. 2002. Educating managers beyond borders. Academy of Management Learning \& Education, 1: 64-76.

Delios, A. 2017. The death and rebirth (?) of international business research. Journal of Management Studies, 54(3): 391-397.

Ghoshal, S. 2005. Bad management theories are destroying good management practices. Academy of Management Learning and Education, 4(1): 75-91.

Harmon, M. 2006. Business research and Chinese patriotic poetry: How competition for status distorts the priority between research and teaching in U.S. business schools. Academy of Management Learning and Education, 5(2): 234-239.

Khurana, R. 2007. From higher aims to hired hands: The social transformation of American business schools and the unfulfilled promise of management as a profession. Princeton, NJ: Princeton University Press.

Khurana, R., \& Spender, J. C. 2012. Herbert A. Simon on what ails business schools, more than a problem of organizational design. Journal of Management Studies, 49(3): 619-639.

Henisz, W. 2011 . Leveraging the financial crisis to fulfill the promise of progressive management. Academy of Management Learning and Education, 10(2): 289-321.

Pettigrew, A., \& Starkey, K. 2016 . From the guest editors: The legitimacy and impact of business schools - Key issues and a research agenda. Academy of Management Learning and Education, 15(4): 649-664.

Pfeffer, J., \& Fong, C. 2002. The end of business schools? Less success than meets the eye. Academy of Management Learning and Education, 1(1): 78 -95.

Shenkar, O. 2004. One more time: International business in a global economy. Journal of International Business Studies, 35(2): $161-171$.

Teegen, H., Doh, J. P., \& Vachani, S. 2004. The importance of nongovernmental organizations (NGOs) in global governance and value creation: An international business research agenda. Journal of International Business Studies, 35(6): 463-483.

Jonathan Doh (jonathan.doh@villanova.edu) is the Rammrath Chair in International Business, Faculty Director of the Center for Global Leadership, and Professor of Management at the Villanova School of Business. His research interests include global corporate responsibility and MNE-NGO interactions. He has published in leading strategy and IB outlets, and is the author of eight books besides serving as Editor-in-Chief of the Journal of World Business. His Ph.D. in Strategic and International Management is from George Washington University. 